\title{
PROFESSOR DR. DRAGANA T. ŽIVKOVIĆ - BIOGRAPHY
}

\author{
Nadežda Talijan * \\ University of Belgrade, Institute of Chemistry, Technology and Metallurgy, \\ Belgrade, Serbia
}

Received 27.09.2017

Accepted 29.09.2017

On 26 November 2016, Professor dr DRAGANA ŽIVKOVIĆ passed away. She was a full-time professor and Dean of the Technical Faculty in Bor, University of Belgrade, Editor-in-Chief of the Journal of Mining and Metallurgy, Section BMetallurgy, as well as the Founder and Chairman of the Committee for Thermodynamics and Phase Diagrams of Serbia.

\section{Academic career}

Professor Dr. Dragana Živković was born on September 13, 1965, in Zaječar (Serbia) where she finished high school. She graduated in 1989 from the Department of Extractive Metallurgy, Faculty of Technology in Bor, University of Belgrade. In 1993 at the same Faculty, she defended the master thesis "Thermodynamic analysis of the quasilinear cross-section $\mathrm{A}-\mathrm{Pb}$ of the ternary system $\mathrm{Pb}-\mathrm{Bi}-\mathrm{Mg}$ ". She obtained her doctorate degree in 1995 with the topic "Comparative thermodynamic analysis of the ternary system Pb-Zn-Ag in order to obtain pure silver from the crude lead".

In the period 1989-2016 she was employed at the Technical Faculty in Bor, University of Belgrade, where she passed through all teaching positions: assistanttrainee (1989), assistant (1993), assistant professor (1996), associate professor (2000), full professor in the field of Extractive Metallurgy and Metallurgical Engineering (2005). She also obtained a full professorship for the field of Industrial Management (2006).

In 2004 she was appointed Head of the Department of Metallurgical Engineering at the Faculty of Technology in Bor. In 2005 and 2006, and since 2014, she also served as Head of the Department of Metallurgy.

Professor Dragana Živković also had the position of the vice-dean for the Scientific Research and International Cooperation in 2009.

In September 2015 Professor Dragana Živković was elected as Dean of the Technical Faculty in Bor.

She was a guest professor at the Central South University in Changsha (People's Republic of China) for the period (2014-2016). At the Faculty of Natural Sciences and

*Corresponding author: NadeždaTalijan, ntalijan@tmf.bg.ac.rs 
Technology, University of Ljubljana (Slovenia) she was a guest lecturer at doctoral studies in 2014.

Since 2007 she was a correspondent member of the Academy of Engineering Sciences of Serbia (AESS), and at the end of 2015 was elected as a full member.

\section{Educational activities}

At the Faculty of Technology in Bor, University of Belgrade, Professor Dragana Živković was engaged in the teaching of courses at all three levels. At Metallurgical Engineering - Basic studies she was teaching: Metallurgical Thermodynamics the $1^{\text {st }}$ part, Iron and Steel Metallurgy and Basics of Extractive Metallurgy. Her engagement in Master studies included Thermodynamics of Materials, whereas in Doctoral studies she was teaching the courses: Metallurgical Thermodynamics the $2^{\text {nd }}$ Part and Pyrometallurgical Processes. She was also engaged in the program of Engineering Management. At Basic studies, she was teaching the course Managing of New Technologies and Innovations, and at Master studies: Strategic Management of New Technologies. She was also active in Doctoral studies teaching lectures on Management with the Knowledge. She was the mentor of dozens of an undergraduate thesis, students' scientific research papers, and master theses. She was also the mentor of many doctoral theses. Professor Dragana Živković was the author and co-author of six university textbooks.

\section{Field of scientific research}

Extensive scientific activities of Professor Dragana Živkovic cover various scientific fields: thermodynamics of multicomponent metallic systems, advanced metallic materials, kinetics of metallurgical processes, environmental protection, archaeometallurgy, management of new technologies and innovations, management in knowledge.

\section{Scientific research activity - project activity}

National research and research projects. From 1989 to 2016 Professor Dragana Živković, participated in the establishment of more than 20 national projects. She was the leader of three projects financed by the Ministry of Education, Science and Technological Development of the Republic of Serbia, and they are as follows: a. within the national energy efficiency program (Project No. EE232025, "Improving the Energy Efficiency of the Technological Process of Pyrometallurgical Extraction of Copper" (2005-2007); b. within the basic research, the field of chemistry Project No. ON142043 "Thermodynamics and Phase Balance of Insoluble Soldering materials" (2006-2010) and Project No. ON172037 "Contemporary Multicomponent Metallic Systems and Nano-Structural Materials with Different Functional Properties" (2011-2016). She was the director of the Project "Caravan of Science Timočki Scientific Tornado - TNT13" (2013), funded by the Center for the Promotion of Science.

Programs of bilateral scientific and technical cooperation. Professor Dragana Živković was the leader of three bilateral projects: two with The People's Republic of China (for the period 2011-2012: "Thermodynamic Investigation of $\mathrm{Zn}-\mathrm{Al}-\mathrm{Me}(\mathrm{Me}=\mathrm{Ni}$, $\mathrm{Ge}, \mathrm{Fe}$ ) Systems Through Comparative Approach - First-Principles Calculations, CALPHAD and Key Experiments", and in 2013-2014: "Comparative Thermodynamic Investigation and Characterization of Advanced Ecological Shape Memory Alloys"), 
and one project with Slovenia (for the period 2014-2015: "Thermodynamic Analysis and Phase Equilibria Investigation in Some Low Melting Alloys of the Zn-Al-Sn-Ga-In System").

International projects. Professor Dragana Živković participated in 15 international projects: COST535 - Thermodynamics of Aluminides - THALLU (20022006); COST531 - Lead-Free Solder Materials - LFS (2002-2006); COST MP0602 Advanced Solder Materials for High Temperature Applications - Their Nature, Design, Process and Control in a Multiscale Domain - HISOLD (2007-2011); COST MP0903 Nano-Alloys (2011-2014); PHARE CBC RO - Creation of the Center for Entrepreneurship and Intercultural Management: Business Development - Success Fulenterpreneurship Practice for Social Organizations in Caras-Severin and Bor (2008-2009); PHARE CBC RO - The Virtual Space of Knowledge - the Way of Integration (2008-2009); DAAD Project - Resita Network - Innovation and Entrepreneurship (2009.-2014); TEMPUS-MCHEM - Modernization of Post-Graduate Studies in Chemistry and Chemistry Related Programs (2010-2013); TEMPUS DEREL - Development of Environment and Resources Engineering Learning (20102013); Erasmus Mundus External Cooperation Window Project Basileus - Balkan Academic Scheme for Internationalization of Learning in Cooperation with EU, 2010; EU HETIP - High Education Teaching Infrastructure Project. Professor Dragana Živković was also active in the Project - Reconstruction of Teaching Buildings and Procurement of Teaching and Research Equipment at the Technical Faculty in Bor (2010-2014); Integrated Innovation Support Program (IISP) - A Project for the Development of a National Network of Technology of Brokers (2012-2013); Development Program WORLD of the University of Zagreb - Development of New Alloys with Shape Change - Multilateral project of the Faculty of Metallurgy in Sisak, University of Zagreb (Croatia), Technical Faculty in Bor, University of Belgrade (Serbia) and Faculty of Metallurgy and Materials, University of Zenica, (2011-2015) (Bosnia and Herzegovina); Erasmus +2014 and JST SATREPS Project - Research on the Integration System of Spatial Environment Analysis and Advanced Metal Recovery to Ensure Sustainable Resource Development, (2014-2019).

Cooperation with the economy. As a responsible project-manager of metallurgical processes, (license No. 385D07106, since 2006), Professor Dragana Živković participated in the realization of 14 projects of cooperation with the economy. She was a member of the National Center for Coordination of Scientific Research and Design Solutions in Metallurgy at the Balkan Center for Coordination of Scientific Research and Project Solutions in Metallurgy. In addition, she participated in the work of the Commission for the Cultural Property of Archaeometallurgy and Industrial Archeology at the Republic Center for the Protection of Cultural Monuments. As a member of the Municipal Team Bor in the LEAP (Local Environmental Action Plan) she contributed to the formation and realization of a number of different engineering solutions.

\section{International cooperation}

Professor Dragana Živković achieved significant international educational and scientific cooperation with numerous universities and research centers in the world and the region (Japan, Italy, Hungary, Czech Republic, Poland, Slovenia, Sweden, France, 
Austria, Croatia, Germany, Romania, Bosnia and Herzegovina, Russia, Canada, Macedonia, Montenegro, People's Republic of China).

As an invited lecturer, Professor Dragana Živković held several lectures at foreign universities (Osaka, Genoa, Miskolc, Changsha, London, Krakow, Brno, Aachen, Porto, Ljubljana, Zenica). She also spent a short time as an expert at several universities and scientific-research institutions in Japan, Italy, Hungary, People's Republic of China, Sweden, Germany, Slovenia.

Professor Dragana Živković was appointed in 2008 as a Vice President of the Research Center for Innovative Materials Design and Application, and since 2010 was elected as a full-time partner for Scientific Center for Material Design and Preparation at Central South University, Changsha, People's Republic of China. Starting from 2014 she became a visiting professor at the Central South University of Changsha. In 2014 she was a lecturer for doctoral studies at the Faculty of Natural Sciences and Technology, University of Ljubljana (Slovenia).

\section{Editing of scientific journals}

Professor Dragana Živković was a Co-Editor of Journal of Mining and Metallurgy (JMM), Section B: Metallurgy, from 1997 to 2012, Editor-in-Chief of the same journal was from 2012 to 2016. Owing to her exceptional editorial work and comprehensive engagement, JMM, Section B, has reached an international status since 2007, with the growing impact factor becoming a leading international journal in the field of Metallurgical Engineering for several years now. Professor Dragana Živković was a member of editorial boards of several international journals: Serbian Journal of Management since, 2006: Journal of Entrepreneurship and Innovation, since 2009; Journal of Powder Metallurgy and Mining, since 2011; Metallurgical and Materials Engineering, since 2012; Rasplavi (Melts), since 2015. She was also a member of editorial boards of national journals: Journal of Metallurgy (JOM) from 2004 to 2012, Annals of EftimieMurgu University Fascicule II - Economic Studies, from 2008, and Copper, from 2010.

\section{Memberships}

Professor Dragana Živković was a member of numerous international and national scientific and professional associations: representative of Serbia in the Associated Phase Diagram and Thermodynamics Committee from 1999 and DC MPNS COST EU in the period from 2010 to 2014; member of the Committee for International Projects COST 531 from 2003 to 2007, and COST MP0602 from 2007 to 2011. She was a member of the Association of Metallurgical Engineers of Serbia and Montenegro, then a member of the Serbian Association of Metallurgical Engineers, member of the Serbian Chemical Society (SCS) (also served as chairman of the SCS branch in Bor from 2005 to 2007), secretary of the Yugoslav Committee for Thermodynamics and Phase Diagrams (1999). In the period from 2003 to 2005, she was a member of the National Center for Coordination of Scientific Research and Design Solutions in Metallurgy at the Balkan Center. From 2004 to 2007 Professor Dragana Živković was a member of the Commission for the Cultural Property of Archaeometallurgy and Industrial Archeology at the Republic Center for the Protection of Cultural Monuments, also a member of the LEAP (Local Environmental Action Plan) of Bor municipality. Starting from 1989 she was also a member of the Chair of Scientific and Organizing 
Committees of numerous international and national scientific meetings. She was actively participating in organizing several workshops, meetings and lectures of guest lecturers from the country and abroad.

\section{Other activities in science promotion}

From 1992 to 2006 Professor Dragana Živković was one of the founders and coordinator of the „Club of Research Students '1902"'. She was one of the initiators of the „Symposium on Thermodynamics by the Differential Diagrams - TDPD“, since 2001. Starting from 2008 she was one of the founders of Resita Network "Entrepreneurship and Innovation", and academic METNET network since 2008. She was one of the creators of "International Students Conference on Mining, Metallurgy, Chemical Engineering, Materials Science and Related Fields" and scientifically popular action the BONIS (Bor Night Researchers), since 2014. Professor Dragana Živković was enthusiastically taking part in activities related to popularization and promotion of science. She actively joined an organization of „Festivals of Science“ in Bor (20122014) and Zaječar (2013). She was one of the authors of the exhibition „The Secret World of Metal and Minerals“, which has been exposed in museums in Bor, Zajecar, and Knjazevac during 2013 and 2014.

\section{Honors and awards}

Professor Dragana Živković deserved the Charter of Honorary Member of the Serbian Chemical Society in 2001. As a recognized scientist in the field of thermal analysis and calorimetry, she was included in the editions WHO IS WHO in Thermal Analysis and Calorimetry (Edited by G. Liptay and J. Simon), Akademia Kiado and Lexica Ltd., Budapest, 2004, pp.242. and also in WHO IS WHO in Thermal Analysis and Calorimetry (Edited by I. M. Szilágyi and G. Liptay), Springer International Publishing Switzerland, 2014, pp.333.

\section{Publications of Scientific Results}

Professor Dragana Živković, as author and co-author, published results from various fields of science and research activities. More than 220 papers were published in well-known international scientific journals (of which 188 papers were published in journals indexed on the SCI list). In national journals, she published 184 papers. She presented more than 650 lectures at scientific national and international conferences, as well other invited lectures (18). Professor Dragana Živković had more than 700 citations (SCOPUS). She was the author and co-author of three monographs. She was the editor of a large number of proceedings of international and national scientific meetings and a guest editor of several conference proceedings with the specific topics. Professor Dragana Živković was the reviewer of more than 50 scientific papers in the leading scientific journals from the SCI list. She was the reviewer of five international projects, several textbooks, and scientific books.

Impressive teaching and scientific research by Professor Dragana Živković achieved in her short life and the professional career are an irrefutable confirmation of her outstanding professional integrity. 
She tirelessly and continuously invested her knowledge, skills, and strength in the development and promotion not only of her home faculty - Technical Faculty in Bor but also in Serbian science as a whole. Through improvement and modernization of teaching, she was always trying to create the best ambiance for scientific research work. She used her numerous personal contacts with foreign colleagues from universities and scientific institutions throughout the region and the world, establishing interinstitutional scientific cooperation. With the selfless commitment, she brought numerous of prominent foreign lecturers organizing scientific workshops and conferences. In this way, she enabled conditions for the further improvement of knowledge through the practice and specialization of younger associates and colleagues in renowned scientific research centers in the world.

She was a person of s versatile creativity, musically educated, playing piano and guitar. She was one of the founders of the choir „Lavirint“ with whom she promoted classical and spiritual national music through numerous concerts in the country and abroad, receiving awards and recognition. She was a member of the instrumental music ensemble „VIS doctors“, a member of a workshop with exhibited works. Also, she was a talented painter and a sculptor. Her paintings and ceramic sculptures were shown at several public exhibitions. She left behind her a few volumes of poetry.

Besides, other important characters of her personality must not be neglected and should be emphasized. She was open-minded, straightforward, cordial, smiling, friendly and kind person, always full of understanding for others. She was an extremely reliable friend. Among the students she was one of the most popular professors, mentor many of them. Above all, she was an endlessly caring and dedicated daughter to her beloved and proud parents Gordana (ethnologist) and Todor (dr primarius gynecologist). Dragana's sudden and premature departure left them in an eternal and deep sorrow.

Professor Dr. Dragana Živković will remain in the lasting memory of many of her colleagues, associates, and friends. Her personality, personal and professional achievements will stay as a deep track that cannot be forgotten not only in this country.

\section{Bibliography}

A complete list of publications of the late Prof. Dr. Dragana T. Zivkovic is available on the Kobson (http://kobson.nb.rs/) and Research Gate (https://www.researchgate.net) websites or Scopus (https://www.scopus.com/) bibliographic databases.

Creative Commons License

This work is licensed under a Creative Commons Attribution 4.0 International License. 